\title{
Oral Storytelling: Resistance and Freeing Voices from the Deep South in Ernest Gaines's AGathering of Old Men
}

https://doi.org/10.33806/ijaes2000.19.2.11

\author{
Faiza Mahfouf and Mahmoud F. Al-Shetawi \\ The University of Jordan, Jordan
}

"The struggle of man against power is the struggle of memory against forgetting"

(Milan Kundera 1981:3).

\begin{abstract}
The study sheds light on the folkloric tradition of oral storytelling which has been used as an act of resistance in Ernest Gaines's A Gathering of Old Men (1983). The marginalized black characters decide to voice their tragedies so as to empower each other to counter the discourse of White supremacy. This tradition becomes a measure of reaching sustainable socio-cultural transformation in the black community. More specifically, the paper relates storytelling, a process of telling personal narratives from an African vantage point, to the theory of Afrocentricity put forward by African-American theorist, Molefe Kete Asante. Steeped in African orature, storytelling endows the African subject with agency to move from the margin to the center. The paper considers how this agency is created throughout this process enabling the disempowered subjects to become speaking powers in recounting their stories and in deciding their own fate in a racist society. Also, it answers the question: How can their oral narratives represent the essential human experience of resistance and transformation, particularly when the social context is one of extreme oppression and violence?
\end{abstract}

Keywords: African-Americans, Afrocentricity, agency, oral storytelling, resistance

In order to combat silence and reclaim their humanity, history and culture, African-American writers speak out against all forms of oppression. Oral storytelling is a unique form of cultural expression that black writers use to resist slavery and reclaim African history, cultural heritage and black identity. AfricanAmerican novelists in particular have mastered various forms of orality(oral narratives) and adapted the spoken word to reach out the listener's heart and mind in every possible way. The oral narrative form is used as a trope of resistance in African-American literature; African-American novelists have presented in their novels disadvantaged black characters who tell personal and local stories stored in their memories in order to counter the stereotypes of African-Americans propagated in Eurocentric discourse and resist White supremacy. To illustrate the function of orality in African-American literature and show its importance for African-Americans in their struggle to assert their African identity, we will examine Ernest Gaines's novel A Gathering of Old Men (1983). This novel best exemplifies the employment of genuine African oral traditions and narrative techniques as acts of resistance and empowerment. 
Oral narratives provide relegated people with a space to substitute monolithic Western discourses and allow them to restore their historical agency (McIsaac 2000: 99). With regard to orature, Ngũgĩ wa Thiong'o states that it is rooted "in the lives of the peasantry. It is primarily their compositions, their songs, their art, which form the basis of the national and resistance culture during the colonial and neo-colonial times" (1986: 95). For him, to face colonialism, which is a tool of oppression, African peasants have resorted to orature as a fundamental medium of displaying resistance to authoritarian regimes, imperial ideologies and cultural dominance. Hence, this folkloric tradition is deemed as a subversive trope which challenges the established order and sets free the African mind and body.

The use of verbal modality in African-American literary narratives ensures the continuity of African heritage and preserves their history. In this regard, Immaculate Kizza rightly states that oral tradition represents "an encyclopedia of the various people's histories, cultural experiences, traditions and values; a record of their feelings, attitudes, and responses to their experiences and environment; and also a tool for preserving and disseminating that knowledge both internally and globally" (2010: 7). This tradition is the inherited historical, cultural, behavioral, and folkloric lore of the African nations which is communicated by the spoken word and orally passed on to subsequent generations.

In analyzing Gaines's A Gathering of Old Men, we will draw on the theoretical tenets of Afrocentricity as postulated by Molefe Kete Asante to find out whether the black characters speak out from the center as agents or from the periphery as victims. In his seminal book Afrocentricity: The Theory of Social Change, Asante (2003) presents his theory known as 'Afrocentricity' as a response to Western hegemony or rather "Westernity" which imposes "its cultural particularity as universal while denying and degrading other cultural, political or economic views" (Asante 2006: 145). The Eurocentric paradigm has produced a state of oppression and negation for black people owing to its refutation of cultural diversity and any other indigenous epistemologies (ibid). In her article "Post-Colonial Literature and Counter-Discourse" (1987), Helen Tiffin argues that "literary universality" guarantees European hegemony which tends to marginalize any text that refuses Euro-cultural assimilation (20). Gaines's novel transfers oral narratives into literature and resists Eurocentric bias through removing Europe from the centre of African reality and depicting black characters who have decided to step out from the circle of silence and passivity to agency and action.

The unconscious adoption of the Western worldview has placed African people at the footnotes in the White man's book (Mazama 2001: 387). In the preeminence of hubristic cultures, African-Americans are entrapped in a condition of oppression, silence, dehumanization, and cultural and historical erasure. For Asante (2003), "Afrocentricity is a mode of thought and action in which the centrality of African interests, values, and perspectives predominate [...] it is the placing of African people in the center of any analysis of African phenomenon" (2). His model suggests the "centeredness" of African culture and history as a remedy for the disturbing conditions caused by white supremacy. People of 
African descent are hailed to regard themselves as centered agents, operating on their own terms in human history. Asante (2003) strongly believes that Afrocentricity cannot be fulfilled without an insistence on the notion of agency which he employs to refer to "an attitude toward action originating in African experiences" (3). Otherwise stated, it is the act of choosing one's fate and reestablishing of one's lost voice from an African-oriented standpoint.

Asante (1998) cogently states that the Afrocentric idea hunts for "ways to unite the country based on mutual respect for the cultural agency of all its people" (xi). It does not advocate the existence of cultural hierarchy; neither does it suggest a substitute for white epistemologies. Demonstrably, it is in pursuit of the reclamation of one's culture and history as a path leading to "centrality". Asante (1998) contends that "By regaining our own platforms, standing on our own cultural spaces [...] we will achieve the kind of transformation that we need to participate fully in a multicultural society" (8). This is the best road to bring about change and overturn the vestiges of "Westernity".

Ernest J. Gaines is one of the most acclaimed African-American novelists whose work A Lesson Before Dying (1993) won the National Book Critics Circle Award. His devotion to write about the Blacks' life and culture in rural Louisiana is called the "Louisiana thing" (Lowe1995: 87). His novels The Autobiography of Miss Jane Pittman (1971) and A Gathering of Old Men (1983) markedly revolve around the unutterable Southern experience of his compatriots as he is the son of a sharecropper. Therefore, his portrayals of slavery and its reverberations are vivid and realistic. To some extent, this affiliation with the South has limited his subject matter; however, it has helped him convey a concrete image of the Deep South (Lowe 1995: 87). In this respect, Thadious M. Davis (2011) rightly states that Gaines makes his fiction out of his racial and cultural memories of the past. His uprootedness makes him "[realign] his spatial location with the remembered plantation past, producing a modern writer whose practice of place [is] always in a time that was and in a space frozen in time-boundness, an incarceral space" (2011: 271). Although this may confine the reader in time and space, it chronicles the historical events in transparency to highlight the workings of the system in the racist South.

A Gathering of Old Men is exemplary for what separates Gaines's novels from other postmodernist works because "the experimentation comes from his use of oral storytelling" as Sarah G. Ford writes (2014: 125). She adds that the African tradition of oral storytelling "contains the power needed to effect change" (ibid: 131). Commenting on the novel, Herman Beavers (2015) states that Gaines deeply invests in the oral tradition wherein people's lives are rendered through the process of storytelling. He remarks that Gaines's narrators tell and retell their stories so as to identify with the plight of their community (26). Beavers adds:

Telling stories [...] has a great deal to do with intervening on conspiratorial, exclusive forms of history [...] But as Gaines's narrators utilize it, storytelling ultimately has a great deal to do with how communities are formed and sustained, a process that occurs across 
barriers of race. And ambivalent though they may be, failure to tell their stories lead to a far worse fate than breaking silence (2015: 27).James W. Coleman argues that Gaines's elders are black people who have freed themselves through personal and communal resources. It is a novel that centers on "communal change through the process of communal narrative, and highlights the stories of black old men who undergo a substantive internal transformation" (2016: 338-339). This critical view shows that communal change takes place and the characters' self-assertion and manhood are restored when the transformative communal narrative process unfolds. Gaines's endeavor to re-center the black male individual voice involves the black male communal voice.

The novel recounts the story of a group of old black men whose confessions about the Cajun man's murder to the Sherriff, Mapes, set up the climax in the novel. Despite the oppression endured, these men have never fought back in their past lives and now come together in an attempt to "stand" for the first time beside their friend, Mathu, and in the face of the white oppressor reclaiming their masculinity and dignity through the process of retelling their personal stories. This act of resistance stipulates the liberation of their repressed voices along with the community. These black men reunite to relate their stories and listen to others. Such verbal performances are to empower the individual and accelerate communal development and social change. They create possibilities for agency and resistance and debunk the ingrained historical fallacies based on unsound arguments.

Gaines is amongst the African-American writers who have worked on wiping out false stereotypes and redrawing a positive image of the African self. For Asante, "the marginalization of Africans within their own histories is a direct result of Europe's writing of Africa's history" (2009: 69). Therefore, it is imperative to dismantle Europe's codes and disturb its centrist philosophy in order to subvert the dominant discourse. In this regard, Tiffin claims that "the rereading and rewriting of the European historical and fictional record" are subversive manoeuvres of cardinal importance as they challenge and erode the hegemonic discourse (1987: 18).

In an interview with Marcia Gaudet and Carl Wooton (1990), Gaines says that he comes "from a long line of storytellers" (7) and tries to recapture the oral stories of his people on the plantation fields and write them down (8). He returns to the practice of oral storytelling to reassert the folkloric tradition and prove it to be a useful trope of resistance and redefinition. In the introduction to Sistren's book Lionheart Gal: Life Stories of Jamaican Women (1987), Honor Ford-Smith states that:

The tale-telling tradition contains what is most poetically true about our struggles. The tales are one place where the most subversive elements of our history can be safely lodged [...] These tales encode what is overtly threatening to the powerful into covert images of resistance to be built on in times when overt struggles are impossible or to build courage in moments when it is. To create such tales is a collective process 
accomplished within a community bound by a particular historical purpose (3).

This supports the argument that the folkloric tradition of telling stories is a form of verbal communication and an act of resistance in the recuperation and rewriting of historical memory.

With regard to Gaines's elders who finally decide to speak, it is interesting to note that it is a positive behavior to break out from the barriers of white supremacy. In this respect, Asante (2003) points out that in "the transcending action", the oppressed dispenses with those traditional behaviors and of defeatism "which hark back to the slave mentality" (129). This notion is practically valid when applied to the characters: Mat, Uncle Billy, Johnny Paul, Tucker, and Gable in their remarkable journey of personal transformation and liberation. They speak because they choose to move away from victimization in the grand drama of humankind. According to Asante (2003), "through a centered positioning of [themselves] within [their] story" (vii), they provide counter-narratives and a direct defiance to the dominant discourse which has located them outside history and humanity. Thus, they acquire agency in order to reassess their historical and cultural values and therefore, invoke a new reality and vision on all facts (3-4).

The novel is read as a critique of the characters' oral storytelling process which pilots them towards social resistance and Afrocentric embrace. One of the most important mechanisms that black Americans use to negotiate chances of survival is orature which Asante refers to as "the sum total of oral tradition, which includes vocality, drumming, storytelling, praise singing, and naming” (1998: 72). According to this, the characters' act of oral storytelling is part of this folkloric tradition and is an essential measure to restore the disremembered African history and cultural heritage through the use of nommo. The latter means the spoken word which has been an effective instrument of communication and transformation for blacks during the difficult times of slavery (95). African-Americans devise distinct communication patterns alternative to those practiced in the Eurocentric discourse in order to assure their survival and defiance.

In literary narratives, oral storytelling gives voice and agency to the oppressed black characters and allows them to become a force capable of subverting the dominant cultures' attempts to negate the existence of African identity, a force which empowers them to resist the particularism of "Westernity" and undo the hegemonic recorded history. The old black men tell their stories to fight for freedom with the aid of the power of the spoken word which brings about progressive change. This strength lies in the dialogues wherein the characters' voice becomes a trope carrying recurring themes of oppression and chaos. On this account, telling stories from a black perspective ensures the opportunity for the characters/storytellers to alter their lives through remembering their individual histories so as to reconstruct their race's history shaped by the White supremacists.

A Gathering of Old Men centers on race relations in the Deep South and recaptures the sense of Gaines's history via the black old men's stories which 
disclose the social repercussions of slavery and the denial of black humanity. These elders take up the position of storytellers and collectively work on creating a space for agency and self-affirmation through voicing the pathetic saga of their lives and thus, engaging a counter-discursive response to the traditional conception of history and White supremacy's assumptions. The gathering of the old black men makes it easy for the writer to pinpoint the importance of oral storytelling tradition as the narratives of his charactersopen the past to revision and champion the cause of the silenced and dehumanized.

With reference to orature, Gaines sets the stage for his characters to start their oral storytelling performances with the intent to rectify the history of negation. This allowance gives birth to agency in them and shepherds them through "Afrocentric victory". The old black men's private stories work as regenerators of the folkloric tradition and providers of a polyphony of voices which challenge the Eurocentric universalism and univocality of the "master narrative". Thereupon, the text is reminiscent of the million victims of the White man's brutality and bigotry.

Gaines presents the collective retelling of personal experiences as a cultural phenomenon to express that African-American history should not be forgotten, erased or retained, but rather recovered and dealt with so as that the disempowered characters can move forward and find back harmony amongst each other. The communal narrative has the power to bring about substantive change. What Asante (2003) calls "revolution" is the old black men's assembly to collectively resist and speak out against White supremacy (vii). Their oral narratives help restore their humanity and dignity and re-locate the black communal voice. Their recalls and confessionals represent a call for social change and defiance in a way that chronicles the fight for a new definition of black manhood and masculinity in defiance of the established regime. Thus, Gaines resorts to the oral tradition in order to both transmit the specificity of the African culture orally and to maintain the memories of past history for future generations. His characters adopt the tradition of oral storytelling as an act of resistance to the oppression, exclusion and negative stereotypes designated by White supremacy, and as a mode of reaching victory through Afrocentricity.

According to Raphael Lambert (2010), the novel is a story of a group of black elders who, "for the first time in their lives, have resolved to stand up to their white oppressors" (106).It unleashes a variety of communal voices and entails themes like Jim Crow laws, oppression, silence, segregation and violence. It is set during the 1970's in Louisiana on the Marshall sugar cane plantation. The novel is told in the first-person point of view by fifteen narrators who let us know about the investigation into the murder of Beau Boutan, a Cajun farmer. The old black men's concatenation of oral stories addresses the "emasculation" issue. Richard Majors and Janet M. Billson succinctly put it:

Historically, racism and discrimination have inflicted a variety of harsh injustices on African-Americans in the United States, especially on males. Being male and black has meant being psychologically castrated-rendered 
impotent in the economic, political and social arenas that whites have historically dominated (1993:1).

The cold truth is that black Americans live in a society that slanders their manhood and questions their mental abilities at every turn.

Gaines reveals the racial problems African-Americans encounter in the South. He allows the old men to talk about the inhuman treatment they have endured and liberate themselves mentally from the Southern code of racism and segregation individually collectively. Thereby, the novel becomes a "story of revenge against a backdrop of enduring racial oppression" (Lambert 2010: 106). The author dives into the heart of the black Louisianan community to explain rather than condemn the African-American's behavior and thinking. The vivid examples can be seen in the old black men Mat, Uncle Billy, Johnny Paul, Tucker and Gable, who keep their stand firm before their community members and Mapes who represents the White man's law.

The novel's tension is felt from the very beginning through "the little gettogether" arranged by the White girl Candy whose family partially owns the plantation. Because she has been raised by Mathu and Miss Merle, she takes on herself the responsibility of killing Beau because she feels indebted to the man who raised her (Gaines: 15). She summons every old man who holds a grudge against Fix to bring his twelve-gauge shotguns and empty five shells, and gather in Mathu's yard. This has been part of her defensive plan to protect Mathu. She addresses Miss Merle: "In case you have forgotten what Fix has done to these people around here, maybe she can remind you. I will not let Mapes or Fix harm my people" (19). Her passage alludes to the brutality and violence that Fix, Beau's father, has practiced on black people in the Marshal parish. As a result, around eighteen old men with shotguns gather at Mathu's yard, each one claiming to be the culprit for the murder and each one telling about the reason behind such action from his own perspective. Their stories reflect racism in all of its rawness and their submissiveness drives them into being individuals who long for freedom. Upon reconnecting with their past and verbalizing it, they put the white man's version of history into question.

The black folks feel the urge to respond to Candy's call and go down the quarters. For them, this is their last chance to be brave (Gaines: 32). They admit that they have not been given a chance to stand up or react against their oppressors. Although they may fear the consequence of their involvement, they feel proud to be doing "something different, for the first time" (40), "something for all the others" (46). They reckon that their defunct people will be proud to see them walking next to each other "[h]eads up and backs straight [...] like soldiers, not like tramps" (49), so as to face the white man's law. Eighteen armed old men arrive at Mathu's yard not having "much to say, just a nod, but in that nod" it could be seen "how proud they was [sic] to be there" (51). Their decision to join is a proof of their readiness to confess.

In an initial sign of defiance, the men's response to Candy's call for help makes of them brave fellows able to stand up for their old friend Mathu whom all 
the villagers accuse. This situation immediately raises tensions and fear amongst the inhabitants of the Marshall plantation. The old men's decision to assemble is an evidence of their "consciousness of oppression" (Asante 2003: 64). At a very elemental level, they prove themselves to be conscious individuals of their oppression, to paraphrase Asante. They are de facto willing to confess so as to protect their friend from being lynched. They become storytellers armed with agency to make heard their own side of the story articulating their condition of oppression to the dispenser of law, Mapes, in the presence of their folks. The "breakdown" process is manifested in their confessions which impart that they have turned their backs to victimization (129). And their articulation of their past stories and miseries is an act to cast away the slave mentality and liberate themselves from the clutches of White supremacy.

The subordinate group of old men attempts to catch up on their powerlessness and ward off the internalization of oppression which Gail Pheterson (1986) defines as follows:

Internalized oppression is the incorporation and acceptance by individuals within an oppressed group of the prejudices against them within the dominant society. Internalized oppression is likely to consist of selfhatred, self-concealment, fear of violence and feelings of inferiority, resignation, isolation, powerlessness, and gratefulness for being allowed to survive. Internalized oppression is the mechanism within an oppressive system for perpetuating domination not only by external control but also by building subservience into the minds of the oppressed groups (146).

In a nommo experience, Mat, one of the old men, decides to join his folks and tells his wife that "Any time we say we go'n stand up for something, they say we are crazy. You right, we all gone crazy" (Gaines: 36). In spite of his old age, he is determined to stand by his folks and says: "You can't stop me, that's for sure" (37). Imbedded in his talk is the assumption that the real insanity is having to bear barbarities and segregation in silence and inaction only because of a darker skin color. Mat's voice is the first individual voice of being aware of victimization in a way that he imparts the gruesome reality beneath the years spent in George Medlow's field, which made the White plantation owner "richer and richer and us getting poorer and poorer [...] The times I done come home drunk and beat you for no reason at all [...]Oliver. How they let him die in the hospital just "cause he was black. No doctor to serve him, let him bleed to death, "cause he was black" (38).The discourse gives an account of the perpetuation of the apartheid system of segregation on grounds of race which results in the emergence of the black underclass. The plight of the poor is "not articulated by the civil rights leaders speaking out against the persistence of inequality; and it [is] nowhere to be found in the thousands of pages written by social scientists on the urban underclass. The word [is]segregation" (Massey and Denton 1993: 1). The endless cycle of grieving due to racial inequalities galvanizes the old man, Mat, into talking about his beloved son's catastrophic death. He resorts to storytelling to resist the imposed silence. His banned memories come in flashbacks to remind us that the 
black race has been exposed to generations of violence, slavery, displacement and apartheid which caused a social death.

In a psychological context, David S. Derezotes (2013) writes that minority populations have suffered historical trauma through experiences including colonialism, slavery, and war. That is, populations like African-Americans have transmitted their trauma across generations (15). Following Derezotes's line of thought, the character, Mat, suffers from a "sociohistorical trauma" because he perpetuates the violence he has endured on his wife. His trauma emanates from witnessing discrimination, poverty, violence, injustice, and death. He seems to be most traumatized by the anticipated loss of his son. Having experienced racial segregation, he internalizes his oppressor's views and perpetuates the cycle of cruel behaviors inflicting his helplessness on his wife. Beside domestic violence, alcoholism is another result of living in a dictatorial environment. To speak of historical trauma is to recognize occurrences as wounds as Mat's storytelling patches the fabric of American history. His story unveils the cruel treatment meted out to blacks during the pre and post-Civil War era in America.

On their way to Mathu's house, the elders' arrival at the cemetery uncages their painful histories. There they start remembering and sharing stories which unveil the system of racism that has ravaged the lives of black people in the Quarters. In other words, the men's foray into the graveyard allows for the process of remembrance. They turn inward to reposition themselves as agents voicing their repressed memories of past cowardice. Gaines empowers them to lay bare their stories of cowardice as the fundamental tool of resisting oppression and self-erasure. Consequently, the cemetery becomes a site of memory, oral culture and resistance where "the old men achieve, at last, a sense of communal unity" (Lambert 2010: 108). As they are remembering their kinfolks, they engage in a storytelling interaction; they speak and listen to each other as part of their African oral tradition activating energy in each other.

The old black men are now assembled to defend their friend, Mathu, and themselves. For them, Beau lies dead today so as to compensate not only for their suffering but their ancestors' as well. For Richard Majors and Janet Billson (1993), "Black men learned long ago that the classic American virtues of thrift, perseverance, and hard work did not give them the same tangible rewards that accrued to whites" (1). This lucidly shows that the village male elders are aware of their oppression and need to find a way to transform themselves into subjects. Indeed, they prove themselves to be storytellers and are now able for the first time, to oppose their masters and rise up against the entrapments of the social system; it is by forcing the Sheriff to listen to the subjective performances of their oral storytelling that defiance is achieved. They retell the stories of a whole race; stories which reveal various signs of injustice, inter alia, bigotry, pain, violence, humiliation, resistance and survival which show the importance of knowing one's history for building communal stamina.

Mapes, the Sheriff, arrives with his deputy at the crime scene and starts to question the dwellers of the quarters. In a verbal sparring, each one of the elders 
avows to be the murderer displaying conspiracy to reinforce the confrontation with Mapes and experiencing a newfound sense of cohesion and fraternity. With an Afrocentric attitude, they respond to the call of resistance as they become conscious of oppression and need to be unified to avenge their decades of dehumanization and marginalization.

Lambert (2010) argues that Mathu's yard has become a sort of stage on which "the old people tell of their grief, past and present, re-enact traumatizing memories, and decry white injustice from slavery to the present" (108). For him, it is "the place where the dominant order and ideology are called into question and reversed, taking the reader far beyond a whodunit into the history of poor African American sharecroppers and the land they have tilled for generation" (ibid). Because these men have not acted valiantly in their past, it is their chance to stand up for themselves and their people.

The law man stares at the old men with exasperation. His intolerance towards the old men who claim to be responsible for the crime is manifested in his use of violence to force them to confess. Rufe tells us that Mapes has:

already used his only little knowledge he knowed how to deal with black folks - knocking them around. When that didn't change a thing, when people started getting in line to be knocked around, he didn't know what else to do. So now, he just stood there, a big fat red hulk, looking down at the ground (Gaines: 93).

Mapes's first response to the old men's resistance is violence but he soon realizes its uselessness and lets them tell their stories. He recognizes that they are not lesser people. Due to their age, it is unquestionable that the old men cannot defend themselves as they no longer have the physical strength Mapes has; yet, because of the power of their nommo and unified goal, they are able to fight back. With an unusual bravery, they, like orators, voice their opposition to the oppressive agent, Mapes.

When Mapes asks Uncle Billy about the supposed-to-be reason of the killing, he immediately recalls a painful experience about his son: "What they did to my boy $[\ldots]$ The way they beat him. They beat him till they beat him crazy, and we had to send him to Jackson. He don't even know me and his mama no more. We take him candy, we take him cake, he eat like a hog eating corn [...] It hurts his mama every time she sees that" (Gaines: 80 ). The dialogue unmasks the dehumanizing results of violence and the great amount of psychological torture Billy and his wife have endured under the white and Cajun domineering owners. Billy's story alludes that "Fix and them" are the guilty that law should have first punished them for his son's violent beating. It is as if he is questioning the Whites' law which has been only applied on black people in a time of heavy discrimination.

Gaines uses flashbacks to revisit some traumatic events to show the brutalities blacks have suffered. Their stories unmask the truth of racism. Again, Gaines empowers another character, Johnny Paul, to articulate his own story. The latter goes into his own flashback remembering the time when they have all lived in serenity as one community until Beau's tractors and trailers come to destroy the 
houses in the quarters. He, like the others, confesses that he has killed Beau. Then, he confuses Mapes when he refers to the disappearance of his nook of happiness: "But you don't see. Yes, sir, what you see is the weeds, but you don't see what we don't see" (Gaines: 89). He carries on: "You still don't see? I don't have to make nothing quick. I can take all the time in the world I want, and it ain't nothing you can do but take me to jail. You can't slap me hard enough to hurt me no more, Sheriff" (ibid).

With an Afrocentric stance, Johnny Paul incites us to have a look at the chapter of the Blacks living on the Marshal plantation. He invites his listeners to think back the old days prior to the arrival of the Boutan family when the elderly residents of the quarters used to sit out with flowers in the yards, used to sing and pray in the church (Gaines: 90-92). He draws a beautiful image of his surroundings that no longer exist with the coming of the Cajuns, saying, "That's why I kilt him [...] To protect them little flowers. But they ain't here no more" (92). His nommo performance sounds powerful and echoing in a way that the attendants respond by nodding their heads in assent to what is being told.

Johnny Paul's nostalgic speech reminisces, first, the sense of togetherness his community has had despite the everyday racist attitudes. Second, it provides us with a reason why he is standing up with his friends - to preserve the memory of his departed people. He will not let the tractor ruin every trace of the black existence in the South. He explains:

I don't see it now, and that's why I did it. I did it for them back there under them trees. I did it 'cause the tractor is getting closer and closer to that graveyard, and I was scared if I didn't do it, one day that tractor was go'n come in there and plow up them graves, getting rid of all proof that we ever was. Like now they trying to get rid of all proof that black people ever farmed this land with plows and mules [...] But I just didn't do it for my own people. I did it for every last one back there under them trees; and I did it for every four-o'clock, every rosebush, every palm-of-Christian ever growed on this place (Gains: 92).

It is beyond the bounds of possibility to obliterate the existence and contribution of black people in America. Gaines gives Johnny Paul the chance to behave Afrocentrically and tell the memory of his people in order to be passed on to future generations as it is vividly important for African-Americans to know their ancestors' past.

The array of storytelling represents an assertive act of defiance in Afrocentric terms. Another illustration is when Tucker states "facts" because "this is the day of reckoning, and [...] [speaks] the truth, without fear, if it mean [he] [has]to spend the rest of [his] life in jail" (Gaines: 94). Like many other characters, he resorts to his community's history to underscore the whites' wrath towards the blacks. He shares his brother's story, Silas. It is about the last black sharecropper who has attempted to preserve his agrarian system and challenge the mechanized farming of the Cajuns. His persistence enables him to win the race only with his mule and plough. Because "a nigger" is not supposed to win: 
So they beat him. They took stalks of cane and they beat him and beat him and beat him. I was there, and I didn't move [...] I saw my brother win that race. But he wasn't supposed to win, he was supposed to lose [...] He was supposed to lose years ago, and because he didn't lose like a nigger is supposed to lose [...] they beat him. And I didn't do nothing but stand there and watch them beat my brother down to the ground [...]we had all seen our brother, sister, mama, daddy insulted once and didn't do a thing about it (96-97).

He even questions the law facing Mapes: "Where was the law? Law said he cut in on a tractor, and he was the one who started the fight. That's law for nigger. That's law"" (97). He justifies: "Out of fear of a little pain to my own body, I beat my own brother with a stalk of cane as much as the white folks did" (98). With his confident attitude, he coerces Mapes to listen to his part of the story and asks forgiveness from his brother.

Tucker's oral storytelling performance emphasizes "the negation of the black folk's past, the eradication of their folklore and culture, the dispossession of their land to the Cajun farmers (with the complicity of the planters), their subsequent rural exodus, and the resulting decrepitude of the quarters" (Lambert 2010: 112). Similar to Catherine Carmier (1964) and Of Love and Dust (1967), Gaines includes Cajun characters primarily to highlight the complicated relations between black and Cajun sharecroppers working on the same plantation in south Louisiana. In The Companion to Southern Literature: Themes, Genres, Places, People, Movements, and Motifs, Joseph Flora and Lucinda H. MacKethan (2001) discuss the relations between the African-Americans and the Cajuns. They say that:

Though both are poor, the racially divided groups show antagonism toward one another [...] Cajuns, who have been able to take over the most productive land mainly because of their skin color. As result of having better land, Cajun sharecroppers raise more money from their crops, thus enabling them to purchase more efficient mechanical harvesters (124).

This is reminiscent of traditional, long-standing feud between blacks and Cajuns competitors in the Deep South. Tucker's speech reveals much about the Jim Crow era during which blacks have barely had opportunities to live or work with dignity. It discloses how this order of racial segregation and disenfranchisement which has restricted the colored people's economic and psychical freedom keeping them in an inferior state.

In Judith L. Herman's estimation, "truth-telling" and speaking about a wrong deed or a terrible event is the first step towards healing and resistance. It is a precondition that restores social order (1992:1). The trauma survivor's acknowledgment strengthens the spiritual transformation. In the novel, Tucker seeks forgiveness for being passive from his dead brother. He even wants to reconcile with him and compensate for his muteness by voicing his story of injustice in recognition of guilt. The passage reveals that the black people's torment stems from their powerlessness when their acquaintances have been in need of help. It is again the discriminatory practices that have emasculated the 
black man. Differentiating between the Blacks and the Cajuns creates a sort of favoritism in the distribution of lands and practice of law. It is discrimination in disguise which will constantly reproduces prejudicial hostilities.

The talking process which condemns the White man's law is not over yet since it is the "payday". Another instance of resistance is when "the poor old nigger" Gable talks about the inexpungible memory of his son. He recounts his adolescent boy's killing accused of raping a white girl:

He wasn't but sixteen years old, half out his mind, still they put him in the 'lectric chair on the word of a poor white trash. They knowed what kind of gal she was. Knowed she had messed around with every man, black or white, on that river. But they put him in that chair 'cause she said he raped her $[. .$.$] Come get him at 'leven, 'cause we go'n kill him at ten-that's$ something to say to- (Gaines: 100-101).

It is again the untellable finally told in a way that Gable tells Mapes the dark side if the law he speaks for. The man admits that he has murdered Beau because: "He was just like that trashy gal. He was just like them who throwed my boy in that 'lectric chair and pulled that switch. No, he wasn't born yet, but the same blood run in all their vein" (102). Gable accuses the whole system and protests at the unfairness of the law's procedures. It is his chance to speak in homage to his executed son's memory.

Since the Jim Crow laws have led to the village elders' 'breakdown', they return to their African oral tradition as a start towards self-liberation marking their breakthrough process. The listeners respond by nodding in agreement with the historical remembrance as it is a collective experience. Of this, Asante (1998) says that in spoken discourse, it is possible to choose word power as one of the main elements of culture sensitive (188). Also, he states that they are speakers employing words in a defense situation in an effort to bring about harmonious relationships with their ancestors and to persuade the villagers to follow a certain course of action. It is then transformation reached through the spoken word.

Therefore, Gaines foregrounds the power of communal discourse as a substitute for black men's submissiveness and defeatism. The impromptu gathering becomes a space wherein the black community can bond, heal and resist. He illustrates the historical heritage and the unforgettable tragedies of slavery and its aftermath. Significantly, the oral narratives allow the old black men to both unveil their traumatized self and reconcile with their old coward self in a way that it begets Afrocentric agency and power to courageously tell their stories and settle their accounts.

The old black folks testify against the White man's historical accounts; they speak of their history, struggles, miseries and pains to listeners including the Sheriff Mapes, his deputy and their multi-ethnic friends. They all bear witness to the "emasculated" black men's transformation and regaining of agency in the South. At this stage, the oppressed blacks' resort to their oral storytelling tradition subverts and creates spaces for resistance (Sium and Ritskes 2013: iii). 
According to Asante (2003), the elders are at the level of thinking black from a centered point where they truthfully revisit their past history and pass it on orally. Their non-violent demonstration against oppression marks the beginning of intelligently dealing with the issue of silence and repression in support of freedom (62-63). Subsequently, they are at the station of commitment to historical reconstruction from an Afrocentric perspective using their own cultural motifs, namely oral storytelling. Their oral performances reconstruct the reality of their life experiences and explain their act of bravery. Their confessionals evince that they have become "totally changed to a conscious level of involvement in the struggle for [their] own mind liberation" (62). This is the manifestation of their "Afrocentric awareness" - the awareness of eradicating every relic of powerlessness (ibid).

Although Candy is a plantation owner who decently treats black people, her possessiveness is illustrated in the last pages of the novel when she endeavors to join the old men who gather inside Mathu's house (Gaines: 72-77). She cannot recognize that her desire to protect "her people" confines their freedom. The fact of disallowing her to join the meeting is "the old men's first deliberate act of disobedience. It is a first concrete step toward the old men's self-liberation as a unified group" (Lambert 2010: 109). It is their collective "transcendence process", to use Asante's words.

However, the ultimate stage of Afrocentricity is not reached until the communal behavior is finally altered. Mathu, who has always been "meanhearted" towards his folks because they have never tried to be African, is now changed by their nommo. He acknowledges how wrong he has been saying "But now I know. And I thank y'all. And I look up to you. Every man in here. And this is the proudest day in my life" (Gaines: 181). The attendants who have plucked up their courage to support him during his hard time are willing to stand till the end to reconfigure their black masculinity and accentuate their solidarity (197). It can be argued, in an Asantean fashion, that these folks make their stories operative in an alien context (Asante 1998: 58). They lead each other out of physical and psychological bondage (140).

As Afrocentricity is the desired end of any nommo experience, the return and death of the character Charlie who is the actual murderer is another change that leads to Afrocentric transcendence. Towards the end of the novel, we learn that he has convinced Mathu, out of cowardice, to take the blame for him but eventually comes back to admit his guilt: "One of y'all standing round ain't doing nothing, go find the law" (Gaines: 183). He tells his fellows: "I'm a man [...] I want the world to know it. I ain't Big Charlie, nigger boy, no more, I'm a man [...] A nigger boy run and run and run. But a man come back. I'm a man" (187). Then he addresses Mapes and Mathu reclaiming the title "Mr" and acknowledging his manhood: "I am a man, Sheriff [...] That's why I come back. I'm a man Parrain. I'm a man, Parrain" (ibid). Charlie experiences a kind of rebirth by his return to prove his awakening and rejection of subjugation. With an Afrocentric agency, he chooses to confront Luke Will who is a cruel friend of the Boutan family and an exemplar of the old rules and manners used against blacks. He tells Mapes: "This 
is my fight" (ibid: 195), showing that dying victoriously in defense of freedom is the perfect alternative to living tyrannized.

The conduct of the black village elders indicates their empowerment, agency and voice to stand against the evil of injustice making themselves worthy of appreciation, recognition and respect as human beings. The "Afrocentric victory" is summarized in the confrontation between Luke Will and Big Charlie who die in the shoot-out whereas the old men are acquitted after the trial. Thus, Gaines re-conceptualizes the notion of "emasculation" through these men's new found self, Mathu's transformation, and the reappearance and death of "Mr." Charlie. The gathering is an opportunity to form a strong kinship bond which contributes to the men's spiritual coping to heal and recoup their strength.

The black elders seize the chance that White man has tried to deny and engage in a process of oral storytelling to defend their identity and rid themselves out of the stereotypes, prejudice and psychological bondage which have kept them silent and subservient for a very long time. In Black Skin, White Masks, Frantz Fanon accounts for such event in Aristotelian terms. In his view, each society has a form of "collective catharsis" which is "a channel, an outlet through which the forces accumulated in the forms of aggression can be released"(1952: 112). For him, there must be avenues through which people can channel outward their distressing emotional material. Gaines's elders choose to be Afrocentric and engage in the experience of the "breakthrough" (Asante 2003: 64). Their talking is a cultural form of expression which externalizes their traumatism and a positive race behavior which defies western allegations. The fact of knowing well their history renders their decision of confessing a wise and courageous response leading to "consciousness of victory" grounded in Afrocentricity (64-65)

Gaines' novels feature black characters as the conveyors of communal memory whereby hidden truths are laid bare and transferred to the coming generations. It is an opportunity for the black protagonists to refashion their old self and place their narratives at the center of the novel. They speak to throw off the stereotype of being silent and inhuman, and to reaffirm their identities and masculinity. Their acts of storytelling and story-listening propel Gaines's text in the realm of polyphony wherein the voices convey "not only individual and collective pain, but also resistance and transcendence" (Clark 1999: 199). The narrators are allowed maximum freedom to tell stories and remind us of the perennial oppression of blacks by the white perpetrator. Hence, the text challenges the "monologic" discourse as the black characters' process of oral storytelling easily lends itself to Mikhail Bakhtin's concept of "dialogism" in a way that it opens the gate for the construction of meaning by the interaction of several perceptions (1973: 18). This works on the destabilization of conventional Western thought in favor of the multiplicity of interpretations in order to resist the "finalizability" of the single-voice discourses (ibid). Thereby, voices from the margin press for the diversity of approaches to knowledge that will encompass the local resources of indigenous peoples. 
Gaines engages history in the oral narratives of his characters in $A$ Gathering of Old Men to show the importance of collective experience, memory and cultural heritage. His texts offer much to the reconstruction of historical truth and to the re-conceptualization of the African culture through challenging the conventional single-voiced narratives of White supremacy. It is through the trope of oral storytelling that Gaines succeeded in unmasking the falsehoods which have enshrouded the "master narrative" for a long time. He permits his characters to tell tales of resistance in order to penetrate into the black history since individual stories are powerful testimonies of a bitter past. Their oral narratives evoke the past and reinsert it in the present freeing the black American voice of the South with the intent to transcend "reality" that cannot be found in the West's documentation of "truth". 
Faiza Mahfouf

Department of English Language and Literature

The University of Jordan

Jordan

faizamahf@outlook.fr

Mahmoud F. Al-Shetawi

Department of English Language and Literature

The University of Jordan

Jordan

alshetawi_m@ju.edu.jo 


\section{References}

Asante, Molefi Kete. (1998). The Afrocentric Idea. Philadelphia: Temple University Press.

Asante, Molefi Kete. (2003). Afrocentricity: The Theory of Social Change. Chicago: African American Images.

Asante, Molefi Kete. (2006). 'Afrocentricity and the Eurocentric Hegemony of knowledge: Contradictions of Place'. In Joseph A. Young and Jana E. Braziel (eds.),Race and the Foundations of Knowledge: Cultural Amnesia in the Academy, 145-155. Urbana: University of Illinois Press.

Asante, Molefi Kete. (2009). 'Resisting Westernity and Refusing Development'. In Kum-Kum Bhavnani, John Foran, Priya Kurian and Debashish Munshi (eds.), On the Edges of Development: Cultural Interventions, 67-71. New York: Routledge.

Bakhtin, Mikhail. (1973). Questions of Literature and Aesthetics. Moscow: Progress Publishers.

Beavers, Herman. (2015). Wrestling Angels into Song: The Fictions of Ernest J. Gaines and James Alan McPherson. Pennsylvania: University of Pennsylvania Press.

Clark, Keith. (1999). 'Re-(W)righting black male subjectivity: The communal poetics of Ernest Gaines's A Gathering of Old Men'. Callaloo, 22 (1): 195207.

https://www.jstor.org/stable/3299962?seq=1\#page scan tab contents (Retrieved On 6 November, 2018)

Coleman, James W. (2016). 'Reimagining the south of Richard Wright: The antiprotest writing of Albert Murray, Raymond Andrews, and Ernest Gaines'. In Fred Hobson and Barbara Ladd (eds.), The Oxford Handbook of the Literature of the U.S. South. New York: Oxford University Press.

Davis M., Thadious. (2011). Southscapes: Geographies of Race, Region, and Literature. Chapel Hill: University of North Carolina Press.

Derezotes, David S. (2013). Transforming Historical Trauma through Dialogue. California: SAGE.

Fanon, Frantz. (1952). Black Skin, White Masks. Trans. Charles Lam Markmann. London: Pluto Press, 1967.

Flora, Joseph M. and Lucinda H. MacKethan. (2001). The Companion to Southern Literature: Themes, Genres, Places, People, Movements, and Motifs. Lousiana: LSU Press.

Ford, Sarah G. (2014). Tracing Southern Storytelling in Black and White. Alabama: University of Alabama Press.

Gaines, Ernest J. (1983). A Gathering of Old Men. New York: Vintage Books.

Gaudet, Marcia and Carl Wooton. (1990). Porch Talk with Ernest Gaines: Conversations on the Writer's Craft. Louisiana: Louisiana State University Press. 
Herman, Judith L. (1992). Trauma and Recovery: The Aftermath of Violencefrom Domestic Abuse to Political Terror. New York: Basic Books.

Kizza, Immaculate N. (2010). The Oral Tradition of the Baganda of Uganda: A Study and Anthology of Legends, Myths, Epigrams and Folktales. Jefferson: McFarland.

Lambert, Raphael. (2010). 'Race and the tragic mode in Ernest J. Gaines's $A$ Gathering of Old Men'. The Southern Literary Journal, xliii (2): 106-125.

Lowe, John. (1995). Conversations with Ernest Gaines. Jackson: UP of Mississippi.

Thiong'o, Ngũgĩ wa. (1986). Decolonising the Mind: The Politics of Language in African Literature. Nairobi: East African Educational Publishers.

McIsaac, Elizabeth. (2000). 'Oral narratives as a site of resistance: Indigenous knowledge, colonialism, and western discourse'. In George Sefa Dei, Budd L. Hall and Dorothy G. Rosenberg (eds.), Indigenous Knowledges in Global Contexts: Multiple Readings of Our World, 89-101. Toronto: University of Toronto Press.

Majors, Richard and Janet M. Billson. (1993). Cool Pose: The Dilemma of Black Manhood in America. New York: Simon and Schuster.

Massey, Douglass and Nancy Denton. (1993). American Apartheid: Segregation and the Making of Underclass. Harvard: Harvard University Press.

Mazama, Ama. (2001). 'The Afrocentric paradigm: Contours and definitions'. Journal o fBlack Studies, 31 (4): 387-405.

Pheterson, Gail. (1986). 'Alliances between women: Overcoming internalized oppression and internalized domination'. Signs, 12 (1): 146-160.

(Sistren with) Ford-Smith, Honor. (1987). Lionheart Gal: Life Stories of Jamaican Women. Toronto: Sister Vision.

Sium, Aman and Eric Ritskes. (2013). 'Speaking truth to power: Indigenous storytelling as an act of living resistance'. Decolonization: Indigeneity, Education \& Society, 2 (1): http://jps.library.utoronto.ca/index.php/des/article/download/19626/16256 (Retrieved on 2 September, 2018)

Tiffin, Helen. (1987). 'Post-colonial literatures and counter-discourse'. Kunapipi, 9 (3): 16-34. http://ro.uow.edu.au/kunapipi/vol9/iss3/4 (Retrieved on 20 May, 2019) 